\title{
KALKOVI - JEDAN OBLIK JEZIČNOGA POSUĐIVANJA U HRVATSKOM I DRUGIM SLAVENSKIM JEZICIMA
}

\section{Povijesna sociolingvistička perspektiva}

$\mathrm{P}$ oznato je da se sa standardološkoga gledišta slavenski jezici načelno mogu razvrstati i s obzirom na njihovu tolerantnost prema kalkiranju, a vezano s tim i na sklonost prema purizmu u pojedinim fazama njihova normiranja (Brozović 1970: 52). Kalkiranje, kao jedan od mogućih tvorbenih postupaka u sustavu normi konkretnoga jezika, nije nužno motivirano ili uvjetovano purizmom. Opća pojava manje ili više spontanoga kalkiranja s klasičnih jezika - grčkoga i latinskoga - izraz je prirodne težnje da se klasična baština i jezično osvijesti u vlastitoj kulturi. Tako se danas u mnogim slavenskim jezicima paralelno i ravnopravno rabi dvostruko, internacionalno i nacionalno nazivlje općega i posebnoga značenja, npr.:

hrv. ortografija - pravopis, ortoepija - pravogovor, lingvistika - jezikoslovlje, prolog - proslov; sln. ortografija - pravopis, ortoepija - pravorečje, lingvistika - jezikoslovje; češ. ortografie - pravopis, ortoepie - spisovná výslovnost, lingvistika - jazykověda, prolog - predmluva; slč. ortografia - pravopis, ortoepia - správna výslovnost, lingvistika - jazykoveda, prológ - prívet, príhovor, predhovor, predslov; polj. lingwistyka-językoznawstwo, prolog - przedmowa; rus. лингвистика - языкознание itd.

S gledišta pripadnosti kulturno-civilizacijskom krugu, pa tako i u odnosu na jezično posuđivanje općenito, uključujući kalkiranje prema klasičnim jezicima, odnosno kalkiranje europeizama, slavenski se jezici mogu podijeliti u dvije skupine: zapadnu i istočnu. ${ }^{1}$

Istočnoslavenski jezici, uključujući i južne koji pripadaju istoj povijesnojezičnoj i civilizacijskoj grupaciji, općenito su u procesu normiranja bili slobodniji od purističkih tendencija, "protočniji”, otvoreniji prema posuđenicama. To npr. potvrđuju mnogi ruski germanizmi - kalkovi i polukalkovi ${ }^{2}$ :

njem. Apfelsine > rus. апельсин, njem. Eisberg > rus. айсберг, njem. Fackel > rus. факел, njem. Leibwache > rus. лейб-гвардия, njem. Lesesal > rus. читальный зал, njem. Platzkarte > rus. плацкарта, njem. Schrift > rus. uрифm, njem. Streikbrecher $>$ rus. штрейкбрехер, njem. Wacht $>$ rus. вахта itd.

Ti su jezici skloniji neposrednoj adaptaciji ili preuzimanju neslavenskih europeizama posredstvom drugih slavenskih jezika, a manje ciljanom, svjesnom kalkiranju. O tome svjedoče brojni ukrajinski i bjeloruski «polonizmi», npr.:

$1 \quad$ Slavia Orthodoxa obuhvaća Rusiju, Ukrajinu, Bjelorusiju, Srbiju, Makedoniju i Bugarsku, a Slavia Latina Poljsku, Češku, Slovačku, Lužicu, Sloveniju i Hrvatsku; usp. Dalewska-Greń 1997: 560.

2 Pod pojmom polukalk misli se na složene izraze u kojima se jedan dio preuzima u neprevedenom, u načelu fonološki, morfološki i ortografski prilagođenom obliku, a drugi se dio doslovno prevodi. S obzirom na to da je riječ o vrsti kalka koji zadržava jedan strani element, ti se izrazi još nazivaju poluposuđenicama, njem. Teillehnwort. Usp. Schumann (1965: 81). 
njem. Druck > polj. druk, ukr. i blr. друк; njem. Farbe > polj. farba, ukr. i blr. фарба; njem. Hauptmann > polj. hetman, ukr. i blr. гетман; njem. Vorhang > polj. firanka, ukr. i blr. фіранка.

Utjecaji drugih slavenskih jezika u toj se grupaciji nisu doživljavali kao tuđi; elementi tuđih, europskih i azijskih jezika (npr. tatarski u ukrajinskom i ruskom, turski u bugarskom, makedonskom i srpskom) nisu ugrožavali gramatičku normu, a na leksičkom su se planu adaptirali ili su jednostavno iščezli. Prilagodba dijela crkvenoslavenskoga leksika te spontano i svjesno posuđivanje iz ruskoga u ovoj je jezičnoj grupaciji opća pojava. Za ove je jezike, dakle, karakterističnije spontano kalkiranje, prije svega prevođenje s klasičnih jezika, npr::

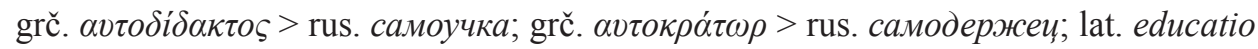
$>$ rus. воспитание; lat. editio > rus. издание, lat. institutio > rus. учреждение.

Slavenski jezici koji pripadaju zapadnom civilizacijskom krugu, uključujući slovenski, hrvatski i dijelom bosanski prostor, pokazuju različit odnos prema kalkiranju europeizama koji je, ovisno o društvenim prilikama, povezan i s purističkim zahvatima. Između poljskoga, koji je imao najravnomjerniji kontinuirani razvitak zapadnoeuropskoga tipa i najmanje potrebe za svjesnim kalkiranjem, te češkoga koji je za kalkiranje bio krajnje otvoren (Brozović 1970: 53), češkom se obrascu tipološki mogu pridružiti gornjolužičkosrpski i slovenski jezik kao jezici u sferi izrazitoga njemačkoga i češkoga utjecaja. Razvitak ostalih jezika ove skupine odvijao se u sferama različitih utjecaja: donjolužičkosrpski pod utjecajem njemačkoga i poljskoga (poljskim posredništvom i češkoga), slovački mađarskoga i češkoga, a hrvatski, jedini od njih sa snažnom književnom tradicijom, pokazujući tek djelomičnu tolerantnost prema kalkiranju, u sferi njemačkih, talijanskih i mađarskih utjecaja. Purističkih obilježja nije lišen ni jedan jezik ove skupine, s tim što su ona najizraženija u češkom, dok su purističke tendencije u poljskom i hrvatskom izrazitije samo u pojedinim fazama standardizacije. ${ }^{3} \mathrm{U}$ svom povijesnom razvitku, do stvaranja političkih zajednica u kojima je jedan slavenski jezik dominirao, ni ovi jezici nisu pokazivali otpor prema posuđivanju iz drugih slavenskih jezika. Naprotiv, to je posuđivanje bivalo i nekritično i nepotrebno, a rezultiralo je pojavom sinonima u jeziku primaocu, među kojima je potpuno adaptirane posuđenice ponekad teško razlikovati od prevedenica. Takvi su npr. hrvatski bohemizmi dostatan (= dovoljan), oblast (= područje), opetovati (= ponavljati), uzajamno (= međusobno) zamak (= dvorac), živalj (= stanovništvo) i dr. (Jonke 1964: 268-269).

Svjesno kalkiranje, karakterističnije za zapadnoslavenske jezike, pretežno se odnosi na prevođenje s njemačkoga, dijelom i s klasičnih jezika, i to izravno ili preuzimanjem kalkova nastalih već u crkvenoslavenskom jeziku, npr.

\footnotetext{
Budući da se ovdje purizam spominje isključivo u kontekstu tolerancije prema kalkiranju ili kao mogući poticaj kalkiranju, nema potrebe za elaboracijom pojedinih purističkih momenata u slavenskim jezicima. Pod pojmom purizam, a njemu je po shvaćanjima i metodama blizak i borbeni antipurizam, podrazumijevamo apriorno negativan, nekritički odnos prema elementima srodnih i nesrodnih jezika, koji narušavaju zamišljeni ideal jezične čistoće (usp. Brozović 1970: 49). Češki su brusiči, kako ih ocjenjuje suvremena bohemistika, u tome smislu ogledni primjer jezičnoga purizma. Suvremeni hrvatski, slovački, ukrajinski itd. "purizam", nije samo reakcija na dominaciju jezika donedavno vladajućih nacija, nego je istodobno izraz oslobođene skrbi za vlastiti jezik. U tom su smislu elementarni purizam i jezična kultura blisko povezani (Katičić 1973-1974: 53).
} 
grč. $\iota \sigma o ́ \varphi v \chi о \varsigma>c s l . r a v b n o d u s ̌ b n b>$ hrv. ravnodušan, sln. ravnodušen, rus. равнодушный (Zett 1970: 254),

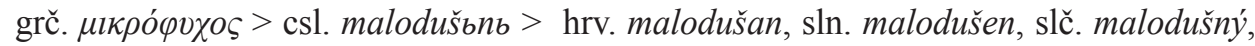
polj. małoduszny, rus. малодушный (Zett 1979: 216),

grč. $\mu \varepsilon \gamma \alpha \lambda \omega ́ \varphi v \chi o \varsigma>$ csl. velikodušbnb > hrv. velikodušan, sln. velikodušen, češ. velkodušný, polj. wielkoduszny, rus. великодушный (Zett 1970: 27, 288, 290) і (Schumann 1958: 54),

lat. misericors $>$ csl. milosrbdbnb (Zett 1970: 219) > hrv. milosrdan, češ. milosrdný, polj. miłosierny, rus. милосердньй.

U primjerima crkvenoslavenskih elemenata bilo koje vrsti u pojedinom slavenskom standardnom jeziku moguće je da su oni u taj jezik ušli izravno ili posredstvom kojega drugoga slavenskoga jezika. U širenju crkvenoslavenizama u raznim slavenskim jezicima ruski je imao najznačajniju posredničku ulogu (Brozović 1970: 76).

Sustav normi češkoga, slovenskoga i gornjolužičkosrpskoga jezika omogućavao je izravno kalkiranje europeizama, dok su u drugim jezicima ove grupacije takve mogućnosti ograničene. Kalkiranje s njemačkoga jezika zajedničko je svim jezicima ove skupine, što je posve razumljivo s obzirom na višestoljetnu političku i kulturnu povezanost zapadnoga slavenskoga svijeta s habsburškom državom, a kulturni utjecaj Beča nadaleko je prelazio granice carstva. ${ }^{4}$

\section{Njemački jezik kao davalac predloška za kalkiranje}

Njemački je jezik imao ulogu davaoca vlastitoga izraza kao uzorka za kalkiranje u hrvatskom i drugim slavenskim jezicima:

njem. Heimatschein > hrv. domovnica, sln. domovnica, češ. i slč. domovskż list, njem. Reinschrift > hrv. čistopis, sln. čistopis, češ. i slč. čistopis, polj. czystopis, njem. Dickhäuter > hrv. debelokožac, sln. debelokožec, češ. tlustokožec, polj. gruboskórzec, rus. толстокожец.

Njemački se predložak u slavenskim jezicima može očitovati na nekoliko načina: postojanjem kalka, naporednom uporabom kalka i posuđenice ili samo posuđenice:

njem. Blumenkohl (< tal. cavol fiore) > hrv. cvjetača / karfiol ${ }^{5}$, slč. karfiol, polj. kalafior, sln. cvetača, češ. květák, rus. ц̧ветная капуста,

njem. häkeln > hrv. kukičati / kačkati / heklati, sln. kvačkati, češ. háčkovat, slč. háčkovat', njem. Sparherd > hrv. štednjak / šparhet (i druge fonološke inačice), slv. štedilnik, češ. i slč. sporák,

njem. Vergaser > hrv. rasplinjač / fergazer, sln. zplinjač, češ. zplynovač, slč. splynovač

njem. Windjacke > hrv. vjetrovka / vindjakna, sln. vetrovka, češ. větrovka, slč. vetrovka, polj. wiatrówka.

Njemački je jezik imao i posredničku ulogu u kalkiranju iz klasičnih i drugih jezika:

grč. europeizam hymenoptera $>$ njem. Hautdflügler $>$ hrv. opnokrilci ${ }^{6}$, sln. kožokrilci, češ. blanokř́ldlí, slč. blanokrídle, polj. błonkoskrzydte,

$4 \quad$ Bez njemačkoga su, uostalom, povijesnojezična slavistička istraživanja teško zamisliva.

5 Na području čakavštine i dijela štokavštine u priobalju, koje je bilo pod utjecajem talijanskoga jezika, postoji izravna talijanska posuđenica kaul.

6 Prema ARJ (9:75) izraz je rječnički prvi put zabilježen u Šulekovim rječnicima (1860) i (1874/75). 
lat. excursio > njem. Ausflug, hrv. izlet, sln. izlet, češ. i slč. výlet (Reiter 1953: 90),

franc. sangfroid $>$ njem. kaltblütig $>$ hrv. hladnokrvan, sln. hladnokrven, češ. chladnokrevný (Reiter 1953: 131), slč. chladnokrvný, polj. zimnokrwisty; rus. холоднокровный (ruski je izraz vjerojatno kalkiran izravno iz francuskoga),

franc. grande puissance $>$ njem. Großmacht ${ }^{7}>$ hrv. velesila, sln. velesila, češ. velmoc, slč. vel'moc,

franc. parole d'honneur $>$ njem. Ehrenwort $>$ hrv. časna riječ ( ̌̌ulek: počtena rǵč), sln. častna beseda, češ. i slč. čestné slovo (Reiter 1953: 44), polj. slowo honoru, rus. честное слово (u ruskom je kalku moguć izravan francuski utjecaj),

tal. cavol fiore > njem. Blumenkohl > hrv. cvjetača, sln. cvetača, češ. květák, rus. цветная капуста,

tal. piombino > njem. Bleistift (kraći oblik za Bleiweißstift) $>$ hrv. olovka ${ }^{8}$, sln. svničnik $(<$ svinec $=$ olovo $)$, polj. ołówek,

engl. > colour-blind > njem. farbenblind, hrv. slijep za boje, sln. slep za barve, češ. barvoslépý (Reiter 1953, 129), slč. farboslepý, polj. ślepy na barwy.

\section{Mađarski jezik kao davalac predloška za kalkiranje}

Mađarski su utjecaji na hrvatski vidljivi i u adaptaciji hungarizama i u kalkiranju:

mađ. illeték $>$ hrv. pristojba, ${ }^{9}$ usp. sln. pristojbina,

mađ. bizottság ${ }^{10}>$ hrv. povjerenstvo,

mađ. örvezetö $>$ hrv. razvodnik.

Sličan utjecaj mađarskoga na slovački potisnuo je češki, koji je srodnome jeziku nudio gotove kalkove. Mađarski je imao i posredničku ulogu u kalkiranju:

njem. Landwehr $>$ mađ. honvéd > hrv. domobran ${ }^{11}$, slč. domobranec,

njem. Beträuter $>$ mađ. megbízott $>$ hrv. povjerenik, slč. povereník.

\section{Talijanski jezik kao davalac predloška za kalkiranje}

Talijanski je utjecaj na hrvatski češće rezultirao lokalno ograničenim preuzimanjem posuđenica, nego tvorbom kalkova. Posuđenice i kalkovi prema talijanskim predlošcima nastajali su uglavnom u jadranskom dijelu hrvatskoga prostora. Talijanski je hrvatskom jeziku

U njemačkom jeziku izraz postoji od 1850. godine (Kluge ${ }^{20} 1967: 273$ ).

8 Hrvatski je izraz prema ARJ (8: 896) mogao imati uzor u talijanskom i njemačkom jeziku. Rammelmeyer (1974 : 283) dopušta mogućnost češkoga posredništva prema danas zastarjelom izrazu oli̊vko.

9 Rammelmeyer (1975: 262) uvrštava riječ pristojba u popis kalkova nastalih prema njemačkom predlošku. Prema ARJ (12: 164) rječnički je registrirana najprije u Frölich-Veselićevu, a potom u Šulekovim rječnicima. I. Nyomárkay (1993: 129-130) taj kalk na osnovi tvorbene strukture i administrativnih pretpostavki dovodi u vezu s mađarskim predloškom.

10 S obzirom na to da riječ povjerenstvo tvorbeno ne odgovara njemačkoj riječi Commision, valja pretpostaviti da je hrvatskoj riječi povjerenstvo kao model poslužio mađarski, a onda vjerojatno i model za prevedenicu povjerenik, bez obzira na to što ima istovjetnu tvorbenu strukturu i značenje kao i njemački adekvat (I. Nyomárkay 1993: 120).

11 M. Rammelmeyer (1975: 171) navodi da je izraz domobran kalkiran prema njemačkom Landwehr, ali dopušta i mogućnost mađarskog utjecaja. I. Nyomárkay (1989: 152) drži da tvorbena struktura i značenje leksema domobran sa sigurnošću upućuju na mađarski predložak. 
bio davalac vlastitoga predloška za kalkiranje i predloška koji je i sam kalk. Uz riječ posjedovati ARJ (10: 919) navodi latinski uzor i potvrde u Mikaljinu, Voltićevu i Stulićevu rječniku. Maretić (1924: XXI i 97) i JS (1971: 211) govore o latinskom podrijetlu ovoga kalka koji se javlja u mnogim europskim jezicima. Osim izravnoga latinskoga uzora ta se riječ posredstvom talijanske riječi possedere učvrstila u hrvatskom jeziku. Jednako vrijedi za izraze posjed ( $<$ tal. possessione $<$ lat. possessio) i posjednik $(<$ tal. possessore $<$ lat. possessor).

Za riječ zavisiti (od čega) ARJ donosi potvrde već iz 17. st., te iz Stulićeva i Vitezovićeva rječnika. Riječ je o kalku koji je prvotno nastao prema latinskome dependere, a potom je učvršćen i talijanskom riječju dipendere.

Vinja (1951: 547-566) navodi sljedeće izraze za koje se može pretpostaviti talijansko posredništvo: gospodstvo prema latinskom dominatio putem talijanskoga dominatione; svršen $<$ tal. perfetto $<$ lat. perfectus; staviti prema tal. mettere $<$ lat. ponere; otvoriti (u prenesenom smislu) prema tal. aprire < lat. aperire. Riječ sklon vjerojatno je starija prevedenica prema tal. inclinato, a ovaj je izraz semantička posuđenica latinskoga inclinare - atus.

Najveći je izravni i posrednički utjecaj talijanskoga na hrvatski bio u razdoblju od 16 . do 18. stoljeća. U 19. stoljeću talijanski se izrazi uglavnom ne reproduciraju izravno. U tom je procesu posredovao i njemački jezik. ${ }^{12}$

\section{Unutarslavensko posredništvo u kalkiranju}

Pojedini slavenski jezici mogli su preuzeti posredničku ulogu u prijenosu kalkova u druge srodne jezike zahvaljujući visokom stupnju svoje standardnosti u pojedinim razdobljima procesa standardizacije (takav je primjer češkoga jezika u 16. stoljeću), povoljnijoj društvenoj situaciji u ključnim povijesnim razdobljima (takav je na početku preporodnoga razdoblja položaj ruskoga u usporedbi s jezicima istočnoga civilizacijskoga kruga i češkoga u odnosu na jezike zapadnoga kruga) te sličnim potrebama srodnih ili kulturološki bliskih jezika. ${ }^{13}$ Iako je češka književnojezična situacija uoči preporoda bila izrazito nepovoljna, neusporediva s poljskom, češka se filologija najranije i najaktivnije posvetila jezičnom normiranju pa se češki književni jezik nužno nametnuo kao normativni obrazac (usp. Brozović 1974). Tako se kontinuirani, povijesni otpor češkoga prema njemačkom manje ili više "preslikao" na zapadnoslavenske jezike koji su se našli u sličnoj situaciji, što je rezultiralo pojavom kalkova prema provjerenom češkom obrascu.

Češko posredništvo u kalkiranju iz njemačkoga jezika pokazuje mnoštvo primjera.

Njemačka složenica Lobgesang kalkirana je u češkom kao chvalozpěv (Reiter 1953: 105). Taj je izraz poslužio kao model za hrv. hvalospjev, sln. hvalospev i slč. chválospev.

12 Viena fu nei tempi asburgici ed è in parte ancora oggi la grande stazione di smistamento di francesismi, italianismi e anglicismi tedeschi in direzione del Sudest. Nel caso nostro tale penetrazione fu resa piu facile dallo spostamento dei maggiori centri di cultura croati in direzione Nord terminata al principio del 19 secolo. Gli elementi romanzi che dopo tale data continuano a affluire nelle città costiere (per es. a Zadar, Split e Dubrovnik) entrano assai di rado nel croato standard che si crea nel crogiolo di Zagabria, ormai città-guida della Croazia, da cui si diffondono molti tedeschismi di origine romanza. (Muljačić 1968: 15).

13 Hrvatski primjer potvrđuje da filologija koja u određenim povijesnim trenutcima poseže za gotovim normativnim modelima i rješenjima jezika drugačije književnojezične tradicije, bez uporišta u vlastitoj književnosti ne može stvoriti stabilnu normu. 
Riječ napadan u ARJ (7: 475) navedena je kao nova riječ nastala prema njemačkom auffällig, auffallend. I u ovom je slučaju moguće češko posredništvo putem izraza nápad$n y ́$, kojega Reiter (1953:125) tretira kao kalk iz njemačkoga jezika.

Riječ pregled (sln. pregled, slč. prehl’ad, polj. przegląd) ima izravni uzor u češkom izrazu přehled, a ta je riječ kalkirana prema njemačkom predlošku Übersicht, Überblick (Unbegaun, 1932: 33).

Mnoštvo kalkova sa sufiksoidom -mjer preko češkoga jezika (-měr) reproducira njemačke tvorbene jedinice -messer i -meter. Taj se sufiksoid javlja najprije u MažuranićUžarevićevu, zatim u Šulekovim rječnicima, a potom je, neovisno o uzorima, razvio vlastitu paradigmatiku.

Dok se češki utjecaj očituje pretežito u hrvatskom, ruski je utjecaj prevladao u srpskom (Brozović 1970: 73). Moguće rusko posredništvo u kalkiranju u hrvatskom jeziku pokazuju sljedeći primjeri:

ARJ (5: 890/891) navodi izraz lakouman (lakomislen) kao noviju riječ i pretpostavlja njezino rusko podrijetlo. Rammelmeyer (1975: 214) drži da se sa sigurnošću ne može utvrditi podrijetlo uzora. S obzirom na tvorbenu sličnost pretpostavlja joj uzor u njemačkoj riječi leichtsinnig i rusko posredništvo u kalkiranju: легкомысленный. Riječ zvanje u značenju zanimanje, poziv zabilježena je uz njemačku riječ Beruf u hrvatskim dvojezičnim rječnicima 19. stoljeća: u Mažuranić-Užarevićevu (1842), Drobnićevu (1846-49), Veselićevu rječniku (1853). U Šulekovim je rječnicima (1860) i (1874/75) zabilježeno: poziv i zvanje (teol.). U prvotnom, doslovnom značenju 'pozivanje' ima starije potvrde kod Belostenca, Stulića, Voltića itd. U hrvatski je jezik vjerojatno ušla posredstvom ruskoga izraza звание.

Hrvatski i slovenski imali su sličnu kulturnu pozadinu, što se očituje u obosmjernom posredništvu u kalkiranju. Tako na primjer ARJ (7: 830) tumači njemački utjecaj u nastanku riječi nedužan. Riječ je najprije potvrđena u Veselićevu (1853), a potom u Šulekovu rječniku (1860). O njemačkom uzoru unschuldig i slovenskom posredništvu nedolžen govore Maretić (1924: 64) i Unbegaun (1932: 31). Pojam vodoravan prvotno je zabilježen u inačicama kod Šuleka (1860): suvodan, ravan kao voda. Riječ je o kalku njemačke riječi wasserrecht (Zett, 1970: 21). U današnjem je obliku zabilježena najprije u Filipovićevu Rječniku (1869). Rammelmeyer (1975: 306) misli da je taj kalk oblikovan pod utjecajem slovenskoga lika vodoraven, koji je, kao i slovački, mogao biti preuzet iz češkoga: vodorovný.

Rammelmeyer (1975: 163) za hrvatsku riječ čitaonica i češku čitárna predmnijeva njemački predložak Lesesaal. Pozivajući se na Breznika navodi da je iz hrvatskoga u slovenski, kao čitalnica, preuzeta 1847. godine. Slavensko je posredništvo moguće i u slovačkom - čitáren̆, poljskom - czytelnia i ruskom читальная (pored читальный зал, gdje se očituje i izravno kalkiranje iz njemačkoga).

\section{Višestruko posredništvo u kalkiranju}

Višestruko posredovanje slavenskih i neslavenskih jezika u kalkiranju vidljivo je u mnoštvu primjera. O slavenskom jezičnom posredništvu svjedoče ovi primjeri:

ARJ (20: 643) pripisuje riječi važan njemačko podrijetlo, a Mažuranić (1908-1922: 
1546), Maretić (1892: 73 i 97) i (1924: 173) i rusko posredništvo. Riječ je u ruski ušla preko ukrajinskoga (важний) iz poljskoga (ważny), u kojemu je prevedenica njemačke riječi wichtig (Rammelmeyer 1975: 299).

Njemački pravni naziv rechtskräftig preproduciran je doslovnim kalkom u hrvatskom pravomoćan, slovenskom pravomočen, češkom pravomocný, poljskom prawomocny, a poljski je izraz poslužio kao model ruskom правомочныцй (Шанский, 1972: 110).

Brojni primjeri očituju i višestruko, neslavensko i slavensko, posredništvo. Engleska složenica steam-engine reproducirana je doslovnim kalkom u njemačkom Dampfmaschine, u češkom djelomičnim kalkom parní stroj i doslovnim parostroj (danas je to arhaizam sa značenjem 'lokomotiva'), preko slovenskoga u hrvatski predložak je prenesen kao djelomični - parni stroj i kao doslovni kalk - parostroj. Usp. slč. párny stroj, polj. maszyna parowa.

Prema engleskoj složenici skyscraper stvoreni su doslovni kalkovi u hrvatskom neboder i ruskom jeziku небоскреб, djelomični kalkovi u slovenskom nebotičnik i njemačkom Wolkenkratzer. Potonji je vjerojatno bio uzorom, tj. imao je posredničku ulogu za češki mrakodrap i srpski oblakoder.

Jezici koji su, zahvaljujući svojoj vodećoj društvenoj poziciji, primarno davali ili prenosili kalkirane europeizme, kao što je npr. slučaj s ruskim, a u određenim razdobljima is poljskim i češkim, podvrgavali su srodne jezike svome utjecaju i onda kad oni takvo posredništvo nisu zahtijevali. Uslijed višestrukoga prijenosa jezičnih elemenata iz jednoga slavenskoga jezika u druge nije uvijek moguće pouzdano tvrditi je li u pojedinim slučajevima riječ o dobro "zamaskiranom" kalku ili o vlastitoj standardnoj tvorbi (Brozović 1970: 48). Takvi su primjeri česti u slovačkom jeziku.

Rezultati međujezičnih utjecaja, koji ujedno zadovoljavaju purističke zahtjeve, najočitiji su na planu stručnoga nazivlja. Stručno je nazivlje «ujedno i jedino područje na kojem je dosad bilo svjesnih koordiniranih akcija u većem opsegu i s više zahvaćenih jezika» (Brozović 1970: 69). Unatoč tomu što na području nazivlja postoji «najveća mogućnost i potreba za općeslavenskom koordinacijom» (isto) u slavenskim se jezicima općenito, a pogotovo u jezicima koji pripadaju istom kulturno-civilizacijskom krugu, uz znatne podudarnosti očituju i prilične razlike, i to u načinu kako se strani predložak reproducira (vrsta kalka), odnosno u postojanju/nepostojanju kalka. U sljedećoj se tablici donosi niz njemačkih riječi koje u slavenskim jezicima istoga, zapadnoga kruga imaju različite ekvivalente: češki su i slovački ekvivalenti tvorbeno i semantički podudarni s obrascem, bilo da je riječ o doslovnim kalkovima ili polukalkovima, naspram hrvatskoga koji prema tim predlošcima nije tvorio kalkove. Slovenski se i poljski primjeri smještaju između tih dviju krajnosti: slovenski kalkira djelomično, a poljski se ponaša različito - preuzima primljenicu, kalkira ili ne kalkira: 


\begin{tabular}{|c|c|c|c|c|c|}
\hline njemački & hrvatski & češki & slovački & slovenski & poljski \\
\hline Wundertäter & čarobnjak & čaroděj/ník & čarodejník & čarovník & czarodziej \\
\hline Wunderschön & čaroban & čarokrásný & čarokrásny & čarobni & czarowny \\
\hline Zeitmäßig & metrički & časoměrný & časomerný & metričen & iloczasovy \\
\hline Zeitmaß & metrika & časomíra & časomiera & metrika & iloczas \\
\hline Schwarzkünstler ${ }^{14}$ & mag & černokněžník & čarodej & $\begin{array}{l}\text { čarodej, } \\
\text { čarovnik }\end{array}$ & czarnoksiężnik \\
\hline $\begin{array}{l}\text { Geschichtskunde, } \\
\text { Geschichte }\end{array}$ & $\begin{array}{c}\text { povijest, } \\
\text { historiografija }\end{array}$ & dějepis, dějiny & $\begin{array}{l}\text { dejepis, } \\
\text { dejiny }\end{array}$ & zgodovina & dzieje \\
\hline $\begin{array}{l}\text { Geschichts- } \\
\text { schreiber }\end{array}$ & povjesničar & dějepisec & dejepisec & zgodovinar & dziejopis/arz \\
\hline Bergsteiger & planinar & horolezec & horolezec & planinec & $\begin{array}{l}\text { alpinista, } \\
\text { taternik }\end{array}$ \\
\hline Völkerkunde & $\begin{array}{l}\text { etnografija / } \\
\text { etnologija }\end{array}$ & národopis & národopis & narodopisje & ludoznawstvo \\
\hline $\begin{array}{c}\text { achtungswürdig, } \\
\text { achtungswert }\end{array}$ & $\begin{array}{l}\text { vrijedan } \\
\text { pažnje }\end{array}$ & pozoruhodný & pozoruhodný & $\begin{array}{c}\text { vreden } \\
\text { pozornosti }\end{array}$ & godny uwagy \\
\hline Gegensatz & suprotnost & protiklad & protiklad & nasprotnost & sprzeczność \\
\hline Gegensätzlich & suprotan & protikladný & protikladný & nasproten & przeciwny \\
\hline Gleichlaufend & $\begin{array}{l}\text { usporedan, } \\
\text { paralelan }\end{array}$ & rovnoběžný & rovnobežný & vzporeden & $\begin{array}{c}\text { równobieżny } \\
\text { (zast.) }\end{array}$ \\
\hline Weihnacht/en pl. & Božić & Vánoce pl. & Vianoce pl. & Božič & $\begin{array}{c}\text { Boże } \\
\text { Narodzenie }\end{array}$ \\
\hline Lustspiel & komedija & veselohra & veselohra & $\begin{array}{l}\text { veseloigra } \\
\text { (zast.) }\end{array}$ & komedia \\
\hline Tierkreis & zodijak & zvěrokruh & zverokruh & $\begin{array}{c}\text { zodiak, } \\
\text { živalski krog }\end{array}$ & zodiak \\
\hline Tierarzt & veterinar & zvěrolékař & zverolekár & $\begin{array}{c}\text { živino-zdrav- } \\
\text { nik }\end{array}$ & weterynarz \\
\hline
\end{tabular}

Kao što je poznato, hrvatski se u preporodnom razdoblju našao u jezično složenijoj situaciji od ostalih slavenskih jezika zapadnoga kruga. ${ }^{15}$ Češki mu je u tim okolnostima nudio modele kalkiranja s njemačkoga, kao i slovenskom, slovačkom i lužičkim jezicima. ${ }^{16} \mathrm{Za}$ kalkiranje s mađarskoga slovački mu nije mogao poslužiti kao primjer, a talijanizme je, kao

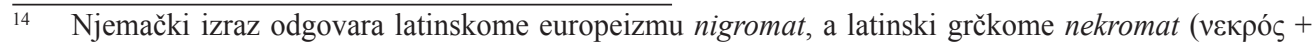

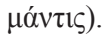

15 Hrvatski je jedini slavenski književni jezik zapadnoga kruga koji je, podredivši se preporodnoj ideji (južno)slavenskoga zajedništva, svoju izvornu književnu baštinu starijih razdoblja podijelio s jezikom drugačijega povijesnoga razvitka, i to iz istočnoga kulturno-civilizacijskoga kruga.

16 Češki je preporod bio u stanovitoj idejnoj, znanstvenoj i operativno-kadrovskoj prednosti pred drugim zapadnoslavenskim jezicima u sferi njemačkoga utjecaja; usp. Brozović 1974: 45-46. 
što smo rekli, preuzimao izravno. Njemački su modeli dijelom primijenjeni i na kalkiranje s klasičnih jezika. Na području znanstvenoga nazivlja mnogi tadašnji kalkovi nisu opstali ni u češkom. Kako hrvatska norma znatno više od češke ograničava mogućnosti svjesnoga kalkiranja, domaći se leksik popunjavao posuđenicama iz drugih slavenskih jezika, među kojima su i kalkovi različitoga podrijetla.

\section{Zaključak}

Iz građe koju nam nude dosadašnja istraživanja možemo zaključiti da slavenski jezici koji pripadaju istočnome ili zapadnome kulturno-civilizacijskom krugu pokazuju različit odnos prema kalkiranju, koji je, ovisno o društvenim prilikama, bio povezan i s purističkim nastojanjima. Istočnoslavenski su jezici, uključujući i južne koji pripadaju istoj povijesnojezičnoj i civilizacijskoj grupaciji, u procesu normiranja bili otvoreniji prema posuđenicama ili preuzimanju neslavenskih europeizama, izravno ili posredstvom drugih slavenskih jezika. Jezici koji pripadaju zapadnom kulturno-civilizacijskom krugu pokazuju različit odnos prema kalkiranju. Poljski je imao najravnomjerniji razvitak i najmanje potrebe za ciljanim kalkiranjem, a češki je za kalkiranje bio potpuno otvoren. Slovenski je bio u sferi izrazitoga njemačkoga i češkoga utjecaja, a slovački mađarskoga i češkoga. Hrvatski je jezik, pokazujući tek djelomičnu tolerantnost prema kalkiranju, bio u sferi njemačkih, talijanskih i mađarskih utjecaja. Pojedini su slavenski jezici u pojedinim razdobljima procesa standardizacije imali posredničku ulogu u kalkiranju.

Sustavnije istraživanje bilo koje jezične pojave pa tako i jezičnoga posuđivanja u slavistici otežava brojnost slavenskih jezika, njihova civilizacijska podijeljenost i kulturološka raznolikost uvjetovana doticajima s različitim susjednim kulturama u promjenjivim društvenim prilikama, kao i isprepletenost njihovih međusobnih utjecaja u milenijskom rasponu. Većina slavenskih jezika do danas nije temeljito istražena ${ }^{17}$ pa se slavistika i u pitanju kalkiranja uglavnom oslanja na građu onih bolje istraženih i gradi određene zaključke na pretpostavkama izvedenim iz rezultata tih istraživanja. Sustavnija komparativna istraživanja različitih tipova kalkiranja i vrsta kalkova (primjerice sintaktičkih ili frazeoloških) u dvojnim i višestrukim razmjenama jezične građe među jezicima u kontaktu vjerojatno bi promijenila naslijeđenu sliku o kulturnopovijesnom identitetu pojedinih slavenskih jezika. U tom nas kontekstu, naravno, prije svega zanima hrvatski.

17 To se prije svega odnosi na slavenske jezike pod dominacijom ruskoga, srpskoga i češkoga u političkim zajednicama koje su razvrgnute devedesetih godina. 